\title{
Combined Carbohydrates Support Rich Communities of Particle-Associated Marine Bacterioplankton
}

\author{
Martin Sperling ${ }^{1,2,3 *}$, Judith Piontek ${ }^{1,3}$, Anja Engel $^{3}$, Karen H. Wiltshire ${ }^{2}$, \\ Jutta Niggemann ${ }^{4}$, Gunnar Gerdts ${ }^{2}$ and Antje Wichels ${ }^{2}$
}

\begin{abstract}
${ }^{1}$ Alfred-Wegener-Institute Helmholtz Centre for Polar and Marine Research, Bremerhaven, Germany, ${ }^{2}$ Biologische Anstalt Helgoland, Alfred-Wegener-Institute Helmholtz-Center for Polar and Marine Research, Helgoland, Germany, ${ }^{3}$ Biological Oceanography, Marine Biogeochemistry, GEOMAR Helmholtz Centre for Ocean Research Kiel, Kiel, Germany, ${ }^{4}$ Research Group for Marine Geochemistry (ICBM-MPI Bridging Group), Institute for Chemistry and Biology of the Marine Environment, University of Oldenburg, Oldenburg, Germany
\end{abstract}

Carbohydrates represent an important fraction of labile and semi-labile marine organic matter that is mainly comprised of exopolymeric substances derived from phytoplankton exudation and decay. This study investigates the composition of total combined carbohydrates ( $\mathrm{tCCHO} ;>1 \mathrm{kDa}$ ) and the community development of free-living $(0.2-3 \mu \mathrm{m})$ and particle-associated (PA) (3-10 $\mu \mathrm{m})$ bacterioplankton during a spring phytoplankton bloom in the southern North Sea. Furthermore, rates were determined for the extracellular enzymatic hydrolysis that catalyzes the initial step in bacterial organic matter remineralization. Concentrations of $\mathrm{tCCHO}$ greatly increased during bloom development, while the composition showed only minor changes over time. The combined concentration of glucose, galactose, fucose, rhamnose, galactosamine, glucosamine, and glucuronic acid in $\mathrm{tCCHO}$ was a significant factor shaping the community composition of the PA bacteria. The richness of PA bacteria greatly increased in the post-bloom phase. At the same time, the increase in extracellular $\beta$-glucosidase activity was sufficient to explain the observed decrease in $\mathrm{tCCHO}$, indicating the efficient utilization of carbohydrates by the bacterioplankton community during the postbloom phase. Our results suggest that carbohydrate concentration and composition are important factors in the multifactorial environmental control of bacterioplankton succession and the enzymatic hydrolysis of organic matter during phytoplankton blooms.

\footnotetext{
Keywords: bacterioplankton community, remineralization, extracellular enzymes, phytoplankton bloom, North Sea, Helgoland Roads, organic matter, spring bloom
}

\section{INTRODUCTION}

It is well established that marine bacterioplankton communities maintain high genetic diversity. As for phytoplankton (Hutchinson, 1961), little is understood, however, how such high diversities are maintained or what determines the community composition in situ. In seasonal seas, phytoplankton development and temperature have repeatedly been reported to structure 
bacterioplankton communities (Pinhassi et al., 2004; RooneyVarga et al., 2005; Sapp et al., 2007; Rink et al., 2011). However, these two factors are not sufficient to explain the high diversity of marine bacterioplankton.

Reactive organic matter is released by phytoplankton and bacteria, often upon viral lysis and grazing, and is a major energy and carbon source for marine bacterioplankton communities. How structure and composition of bacterioplankton communities are influenced by spatial and temporal differences in organic matter (OM) composition is only poorly resolved. Numerous compounds in the vast pool of marine OM may support species-rich bacterioplankton communities, which are, in turn, able to efficiently remineralize large portions of the OM. In laboratory experiments, bacterioplankton exhibit specific OM uptake at a class and clade level (Pernthaler et al., 2002; Elifantz et al., 2005; Alonso-Sáez and Gasol, 2007). Single low molecular weight (LMW) compounds have been shown to structure bacterial communities (Gómez-Consarnau et al., 2012). The in situ structuring of bacterial communities is thought to be more complicated, involving a combination of available substrates, inorganic nutrients, physical factors and competition among bacteria (Gómez-Consarnau et al., 2012).

While large portions of marine OM are still chemically uncharacterized, carbohydrates have been identified as the largest fraction of characterized marine OM (Pakulski and Benner, 1994; Amon and Benner, 2003). Recent studies of the transcriptomic activity of marine bacterioplankton suggest that bacterial community composition and diversity are related to the genus-specific expression of metabolic genes (Teeling et al., 2012; Gifford et al., 2013), in particular those for carbohydrateactive enzymes. This allows for a succession of diverse bacterial strains that thrive on various forms of algal-derived OM during the spring phytoplankton bloom in the North Sea (Teeling et al., 2012).

Bacteria can take up LMW compounds as large as $0.6-0.8 \mathrm{kDa}$ through porins and slightly larger compounds via TonBdependent transporters (Weiss et al., 1991; Teeling et al., 2012) to meet their energy and carbon demands. Compounds with higher molecular weight must be hydrolyzed into smaller subunits by extracellular enzymes, prior to uptake. These are released by bacteria into the environment or attached to the outer cell membrane (Chróst, 1991). Heterotrophic bacteria have been found to favor HMW- over LMW-dissolved organic carbon (DOC), likely because HMW-DOC is less diagenetically altered and therefore more reactive and more usable (Amon and Benner, 1996). This underpins the importance of enzymatic hydrolysis as the first step in the bacterial degradation of complex carbohydrates. In addition to control through substrate availability, there is a close link between bacterioplankton species richness and diversity of $\beta$-glucosidase ( $\beta$-Glcase) isoenzymes (Arrieta and Herndl, 2002), which likely influences the effectiveness of substrate utilization.

Understanding the interaction between bacterioplankton and diverse $\mathrm{OM}$ is important for our understanding of biogeochemistry (Azam et al., 1983). It is also an urgent matter, as there is growing evidence for the high potential of ocean acidification to alter phytoplankton OM production (Borchard and Engel, 2012; Engel et al., 2014), combined with changes in bacterial community composition (Allgaier et al., 2008; Krause et al., 2012; Sperling et al., 2013) and bacterial degradation activity (Grossart et al., 2006a; Tanaka et al., 2008; Piontek et al., 2013).

This field study aims to fill the gap between laboratory studies of single bacterial groups or carbohydrates and results inferred from in situ meta-transcriptomics. It investigates the influence of carbohydrate composition and concentration in seawater on the community structure of free-living (FL) and particle-associated (PA) bacteria by combining, for the first time, a detailed analysis of the composition of total combined carbohydrates (tCCHO; $>1 \mathrm{kDa}$ ) using high-performance anion-exchange chromatography coupled with pulsed amperometric detection (HPAEC-PAD) and bacterial community analysis using Automated Ribosomal Intergenic Spacer Analysis (ARISA) and Catalyzed Reporter Deposition-Fluorescence In Situ Hybridization (CARD-FISH). Furthermore, it investigates the extracellular enzymatic activity of the bacterial community in relation to carbohydrates and the wide range of physicochemical and biological factors at the transition from winter to spring in the temperate North Sea.

\section{MATERIALS AND METHODS}

\section{Sampling}

Surface water ( $\sim 1 \mathrm{~m}$ depth) was collected in a 10 -L plastic carboy in the morning twice a week from February 2nd to May 18th 2010 from a research vessel at the long-term North Sea monitoring station "Helgoland Roads" between the islands of Helgoland $\left(54^{\circ} 11^{\prime} 03^{\prime \prime} \mathrm{N}, 7^{\circ} 54^{\prime} 00^{\prime \prime} \mathrm{E}\right)$ in the German Bight, North Sea (see Wiltshire and Manly, 2004; Wiltshire et al., 2008).

\section{DNA Collection and Extraction}

After pre-filtration through $10 \mu \mathrm{m}$-pore size filters, PA bacteria were collected by filtering $2 \mathrm{~L}$ of seawater through $3-\mu \mathrm{m}$ filters (TCTP and TSTP, $47 \mathrm{~mm}$, Millipore, Billerica, MA, USA). To collect FL bacteria, $500 \mathrm{~mL}$ of the resulting filtrate was filtered through a $0.2-\mu \mathrm{m}$ filter (GTTP, $47 \mathrm{~mm}$, Millipore, Billerica, MA, USA). All filters were cut into three equal pieces using sterilized pincers and scalpel and stored in a $2 \mathrm{~mL}$-reaction tube at $-20^{\circ} \mathrm{C}$ until processing.

The DNA from all three filter pieces was extracted simultaneously using lysozyme followed by phenol-chloroformisoamylalcohol purification (as described in Sapp et al., 2007) with the addition of $0.002 \mathrm{mg}$ of sterile Polyvinylpolypyrrolidone (PVPP) to bind larger contaminants. The DNA was re-diluted in $20 \mu \mathrm{L}$ of PCR-grade water and the concentration measured using a NanoQuant Plate and an infinite M200 plate reader (both Tecan, Switzerland).

\section{Bacterial Community Analyses}

Automated Ribosomal Intergenic Spacer Analysis (ARISA), as described in Sperling et al. (2013) was used to investigate PA $(3-10 \mu \mathrm{m})$ and FL $(0.2-3 \mu \mathrm{m})$ bacterial communities. In brief, the Intergenic Spacer (IGS)-region was amplified using 
the forward primer L-D-Bact-132-a-A-18 (5'-CCG GGT TTC CCC ATT CGG-3' ${ }^{\prime}$ and the fluorescence-labeled reverse primer S-D-Bact-1522-b-S-20 (5'-TGC GGC TGG ATC CCC TCC TT- $\left.3^{\prime}\right)$ described by Ranjard et al. (2000). Length separation was achieved in a 4300 DNA analyzer (Li-Cor, Bad Homburg, Germany) using polyacrylamide gels (5.5\% ready to use matrix, Li-Cor Biosciences, Bad Homburg, Germany). The PCR products were amended with Blue Stop Solution (Li-Cor, Bad Homburg, Germany) in a $1: 1$ ratio, and the size standard IRDye ${ }^{\circledR} 700,50-$ 1500 bp (Li-Cor, Bad Homburg, Germany), was applied. The wells were loaded with 0.25 or $0.5 \mu \mathrm{L}$ of samples, depending on the amount needed to visualize bands clearly. Values obtained from the application of a $0.5 \mu \mathrm{L}$ sample were divided by two prior to data analysis. The volume of applied sample was confirmed to have no significant effect on Sørensen-similarities in the PA(ANOSIM, $R=0.12, p=0.20$ ) and FL- (ANOSIM, $R=-0.15$, $p=0.72$ ) fractions. The software package BioNumerics (Applied Math, Sint-Martens-Latem, Belgium) was used to analyze the gel images. The bands with a length between 300 and $1500 \mathrm{bp}$ were binned into size classes (termed "ARISA-band-classes") to correct for minor length variations of the IGS regions between lineages with almost identical $16 \mathrm{~S}$ rDNA-sequences. Bins of $3 \mathrm{bp}$ were used for fragments up to $700 \mathrm{bp}$ in length, bins of 5 bp were used for fragments between 700 and 1,000 bp, and bins of $10 \mathrm{bp}$ were used for fragments larger than 1,000 bp (Brown et al., 2005; Kovacs et al., 2010). In this way, the total number of bands, i.e., community richness, was reduced by approximately 4.5 and $1 \%$ for the PA and FL bacterial data, respectively.

Values for Catalyzed Reporter Deposition Fluorescence In Situ Hybridization (CARD-FISH) of non-prefiltered samples on 0.2- $\mu \mathrm{m}$ filters were taken from Teeling et al. (2016).

\section{Analysis of Physicochemical and Phytoplankton Parameters}

Physicochemical and phytoplankton parameters were investigated on a weekday basis (Monday-Friday) as part of the Helgoland Roads LTER time series, which is also accessible via the open database PANGEA ${ }^{1}$ (Wiltshire and Manly, 2004; Wiltshire et al., 2008). Surface water samples were investigated using standard colorimetric methods (Grasshoff et al., 1999). Salinity was measured by converting conduction, as measured with an inductive salinometer (GDTAutosal8400B Salinometer, Guildline, ON, Canada), to salinity using UNESCO tables (Cox and Culkin, 1976; Wiltshire et al., 2008). A fluorometer (bbe Moldaenke, Kiel-Kronshagen, Germany) was used to measure Chl a concentrations (Wiltshire et al., 2009). Inorganic nutrients (phosphate, silicate, ammonium, nitrate, and nitrite) were measured in the laboratory using the methods of Grasshoff et al. (1999) and Knefelkamp et al. (2007). Measurement of $\mathrm{pH}$ according to the National Bureau of Standards (NBS) scale was performed after samples were brought back to the laboratory. The $\mathrm{pH}$ difference due to the difference between in situ temperature and measurement temperature in the lab was

${ }^{1}$ http://www.pangea.de corrected after the method of Gieskes (1969) using the following equation:

$$
\mathrm{pH}_{\text {in situ }}=\mathrm{pH}_{\text {measured }}+0.0114\left(t_{\text {measured }}-t_{\text {in situ }}\right)
$$

where $t_{\text {measured }}$ is the temperature in ${ }^{\circ} \mathrm{C}$, measured simultaneously with $\mathrm{pH}$ using a combined electrode (ProLab $3000 \mathrm{pH}$ meter, IoLine $\mathrm{pH}$ combination electrode with temperature sensor) calibrated with standard buffer solutions (all materials: SI Analytics, Mainz, Germany).

\section{Particulate and Dissolved and Total Organic Carbon}

Particulate carbon was collected on pre-combusted GF/F filters (25 mm, Whatman Nuclepore), which were stored at $-20^{\circ} \mathrm{C}$ until analysis. The filtration volume $(80-380 \mathrm{~mL})$ was adjusted to the particle loading of the seawater. Filters were treated with $200 \mu \mathrm{L}$ of carbon-free $\mathrm{HCl}(0.2 \mathrm{~N})$ to remove inorganic carbon and dried at $60^{\circ} \mathrm{C}$ for approximately $48 \mathrm{~h}$. After drying, filters were packed into small $\mathrm{Zn}$-cartridges and analyzed using an elemental analyzer (Euro EA 3000, EuroVector Instruments \& Software, Italy).

For analysis of DOC concentration, seawater was filtered through combusted $\left(400^{\circ} \mathrm{C}, 4 \mathrm{~h}\right) \mathrm{GF} / \mathrm{F}$ filters ( $0.7 \mu \mathrm{m}$, Whatman), and $15 \mathrm{~mL}$ was sealed in combusted glass ampoules. Samples were stored at $-80^{\circ} \mathrm{C}$ in the dark. Some of the ampoules were damaged during transport to the mainland, resulting in reduced temporal resolution. Acidified samples $(\mathrm{pH} 2, \mathrm{HCl})$ were analyzed using high-temperature catalytic oxidation (Sugimura and Suzuki, 1988) on a Shimadzu total organic carbon (TOC)$\mathrm{VCPH}$ instrument with analytical precision better than $5 \%$ for three replicate samples. Accuracy was tested in each run against deep Atlantic seawater reference material (D.A. Hansell, University of Miami, FL, USA) and was better than 5\%.

Total organic carbon (TOC) was calculated as the sum of particulate organic carbon (POC) and DOC.

\section{Carbohydrate Analysis}

Analysis of total combined carbohydrates (tCCHO; >1 kDa), which are a portion of high molecular weight organic matter (HMW-OM), was performed according to Engel and Händel (2011). In brief, two replicate seawater samples $(20 \mathrm{~mL}$ each) were transferred to pre-combusted glass vials using pre-rinsed disposable syringes and immediately stored at $-20^{\circ} \mathrm{C}$ until processing of the samples. Samples were desalinated using membrane dialysis (1 kDa MWCO, Spectra Por). Carbohydrate monomers that were produced from acid hydrolysis $(1 \mathrm{M} \mathrm{HCl})$ and subsequent acid evaporation $\left(\mathrm{N}_{2}\right)$, were analyzed on a Dionex ICS3000 system combining high performance anion exchange chromatography (HPAEC) and pulsed amperometric detection (PAD) using a Dionex CarboPac PA10 analytical column $(2 \times 250 \mathrm{~mm})$ coupled to a Dionex CarboPac PA10 guard column $(2 \times 50 \mathrm{~mm})$. The autosampler (Dionex AS50) was maintained at $8^{\circ} \mathrm{C}$, and $17.5 \mu \mathrm{L}$ of sample was injected for each analysis. After every second sample, $17.5 \mu \mathrm{L}$ of a mixed sugar solution was injected for standardization. Blanks (ultrapure water; Milli-Q) were analyzed using the same procedure used 
for the samples and subtracted from sample concentration. We identified 12 carbohydrate monomers (Supplementary Table S1). The neutral sugars arabinose (Ara), fucose (Fuc), galactose (Gal), glucose (Glc), and rhamnose (Rha) were investigated, as well as the co-eluting sugars mannose and xylose (Man/Xyl). The acidic sugars galacturonic acid (GalUA), gluconic acid (GlcA), glucuronic acid (GlcUA) and muramic acid (Mur) were measured. In addition, the concentrations of the two amino sugars galactosamine (GalN) and glucosamine (GlcN) were determined. The detection limit for the method was $1 \mathrm{nmol} \mathrm{L}{ }^{-1}$. Values for all sugar components and standard deviations can be found in Supplementary Table S2.

\section{Extracellular Enzyme Activity}

The activity of extracellular enzymes was determined by the use of fluorogenic substrate analogs (Hoppe, 1983). The rates of $\beta$-glucosidase, leucine (leu)-aminopeptidase, and alkaline phosphatase were assessed from the hydrolysis of 4methylumbelliferyl- $\beta$-glucopyranoside, L-leucyl-4-methylcoumarinylamid-hydrochlorid and 4-methylumbelliferyl-phosphate, respectively. The substrate analogs were added to seawater samples at final concentrations of $1,5,10,20,50,80$, 100, and $200 \mu \mathrm{mol} \mathrm{L} \mathrm{L}^{-1}$ to determine enzyme kinetics. To measure fluorescence, the infinite M200 plate reader (Tecan, Männedorf, Switzerland) was used. The fluorescence emitted by 4 -methylumbelliferone (MUF) was detected at $365 \mathrm{~nm}$ excitation and $440 \mathrm{~nm}$ emission wavelengths, and that of 7-amino-4-methyl-coumarine (AMC) was detected at $380 \mathrm{~nm}$ excitation and $440 \mathrm{~nm}$ emission wavelengths. Fluorescence units were converted into concentrations of MUF or AMC after calibration with standard solutions. Enzymatic rates were calculated from the increase in MUF or AMC concentration, over time. An initial fluorescence measurement was conducted immediately after the addition of the substrate analog, followed by two measurements within $4 \mathrm{~h}$ of incubation in the dark at the approximate in situ temperature for the sampling day $\left(1-8^{\circ} \mathrm{C}\right)$. The initial fluorescence was subtracted as background fluorescence from the fluorescence measured at each time point. The slope of the linear regression between incubation time and the concentration of the fluorescent marker was applied for rate calculations. Experimental data were fitted using the Michaelis-Menten equation to determine the maximum velocity $\left(V_{\max }\right)$ of the enzymatic reactions. To estimate the amount of substrate hydrolyzed by $\beta$-glucosidase $(\beta$-Glcase) during the post-bloom phase, we calculated the enzymatic rate for each day using a mean post-bloom concentration of $2.13 \mu \mathrm{mol} \mathrm{L}^{-1} \mathrm{Glc}$. The resulting mean rate $\left(83.05 \mathrm{nmol} \mathrm{L}^{-1} \mathrm{~d}^{-1}\right)$ was multiplied by the number of days (26) in the post-bloom phase.

\section{Statistical Analysis}

For multivariate statistical analyses, the software package PRIMER v. 6 and the add-on PERMANOVA+ (both PRIMER-E, Auckland, New Zealand) were used. The analyses were performed using Sørensen-similarity-matrices generated from square-root transformed ARISA-band-class data. To test for community assemblage differences between phytoplankton bloom phases, permutational multivariate analysis of variance
(PERMANOVA) was applied. Distance-based multivariate multiple regression (DistLM) was used to calculate correlations of community composition to environmental factors, and distance-based redundancy analysis (dbRDA) was used to visualize these correlations. For this analysis, the highly collinear combined carbohydrates (colCHO, Pearson $r>0.8)$ Fuc, Rha, Gal, Glc, GalN, GlcN, and GlcUA were pooled.

\section{RESULTS}

\section{Phytoplankton Bloom Development}

Chlorophyll $a$ ( $\mathrm{Chl} a$ ) was used to determine the state of the phytoplankton bloom. After low Chl a concentrations $(<1 \mu \mathrm{g}$ $\mathrm{L}^{-1}$ ) in February, a diatom-dominated spring phytoplankton bloom developed at the long-term monitoring station "Helgoland Roads" (54 $\left.11^{\prime} 03^{\prime \prime} \mathrm{N}, 7^{\circ} 54^{\prime} 00^{\prime \prime} \mathrm{E}\right)$. Bloom development started in mid-March and reached $\mathrm{Chl} a$ values of up to $12 \mu \mathrm{g}$ $\mathrm{L}^{-1}$ in April (Figure 1A). The onset of the bloom coincided with a strong peak in dissolved inorganic phosphate (DIP) concentration and a slight increase in sea surface temperature (Figures 1C,D). The bloom development was accompanied by rising seawater $\mathrm{pH}$. Salinity decreased from approximately 34 in February to approximately 31 at the end of April (Figure 1B). The phytoplankton bloom terminated in late April, likely due to the depletion of DIP and silicate $\left(\mathrm{SiO}_{2}\right)$ (Figure 1D).

\section{Organic Carbon and Carbohydrate Composition}

During the bloom, POC increased with diatom abundance, reaching a maximum of $54 \mu \mathrm{mol} \mathrm{L}^{-1}$ (Figure 1B), while

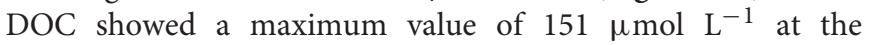
peak of the bloom. TOC values were calculated as the sum of POC and DOC and reached maximum values of 135 and $187 \mu \mathrm{mol} \mathrm{\textrm {L } ^ { - 1 }}$ before and after the phytoplankton bloom, respectively. Bloom development resulted in the accumulation of tCCHO, which contributed up to $14 \%$ of TOC in the post-bloom phase (Figure 2A). The subsequent decline in tCCHO and POC lagged behind the decrease in diatom cell numbers and Chl $a$ (Figures $\mathbf{1 A}, \mathbf{B}$ and $\mathbf{2 A}$ ). The carbon contribution of tCCHO to TOC strongly increased during the bloom (Figure 2A). Several carbohydrates in HMW-OM showed very similar temporal dynamics (Pearson $r>0.8$ ) during spring 2010. Therefore, for the statistical analysis, glucose, galactose, fucose, rhamnose, galactosamine, glucosamine, and glucuronic acid were pooled into a single factor and designated as collinear $\mathrm{CHO}$ (colCHO). Its concentration strongly increased toward the end of the phytoplankton boom and maintained high values during the early post-bloom phase (Figures 2BD). In contrast, Ara showed concentrations near the detection limit during the entire study, while GalUA revealed strong dynamics unrelated to the phytoplankton bloom. Throughout the bloom, the composition of tCCHO was dominated by neutral sugars (60-90 mol\%). Glc alone contributed an average $53 \mathrm{~mol} \%$, with maximum concentrations of $3 \mu \mathrm{mol}$ monomer 

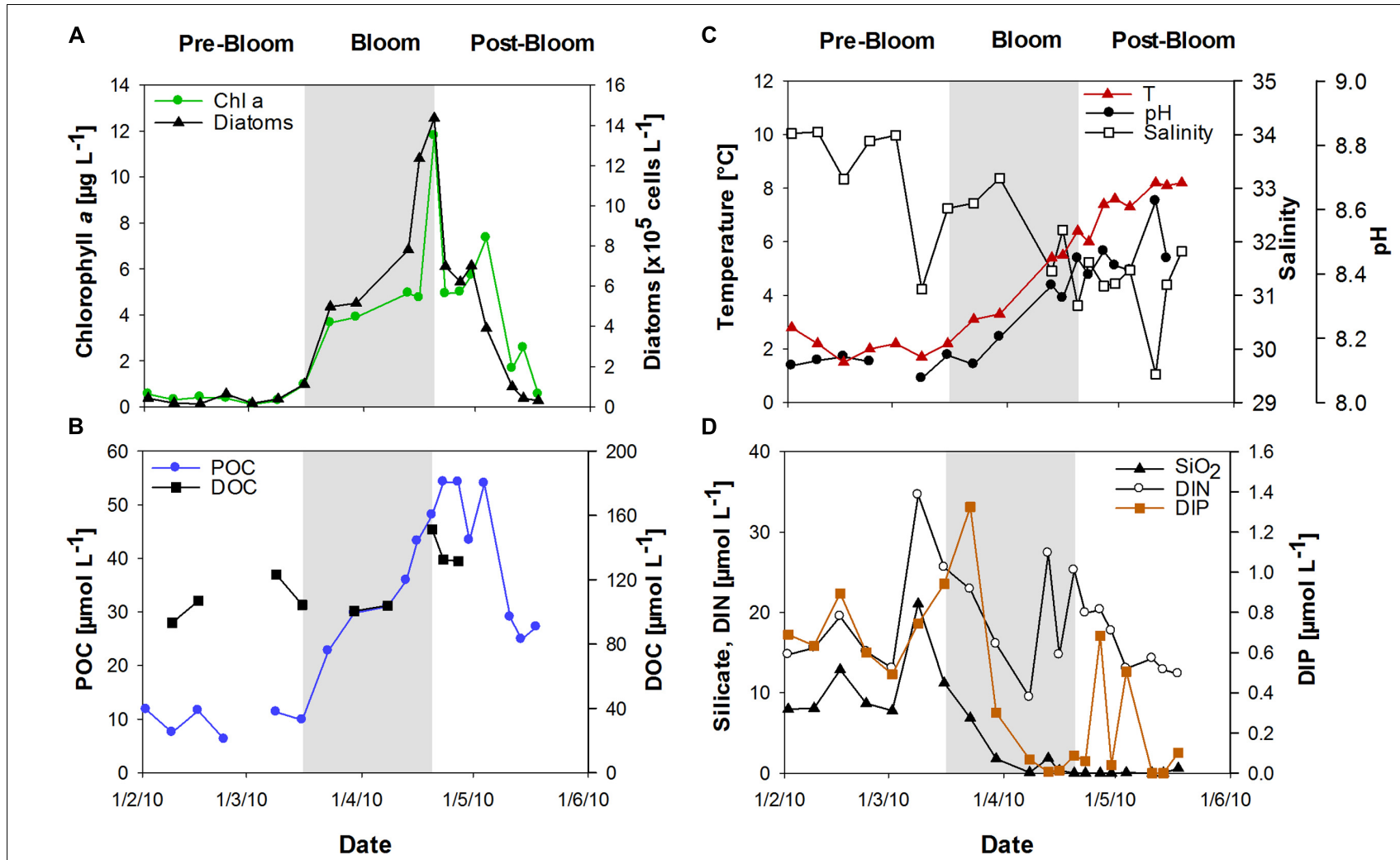

FIGURE 1 | Development of the spring bloom at Helgoland Roads in 2010. (A) Chlorophyll a (Chl a) concentrations and diatom abundance, (B) Temperature, salinity and seawater $\mathrm{pH}$, (C) Particulate organic carbon ( $\mathrm{POC}$ ) and dissolved organic carbon (DOC), (D) Inorganic nutrients comprising silicate $\left(\mathrm{SiO}_{2}\right)$, dissolved inorganic nitrogen (DIN) and dissolved inorganic phosphorous (DIP).

equivalent $\mathrm{L}^{-1}$ in the late bloom and post-bloom phase (Figure 2A). Concentrations of Man/Xyl, Fuc and Gal increased with the onset of the phytoplankton bloom and maintained high values during the post-bloom phase, though maximum concentrations of $0.2-0.4 \mu \mathrm{mol} \mathrm{L} \mathrm{L}^{-1}$ were approximately an order of magnitude lower than that of Glc (Figure 2B). $\mathrm{Man} / \mathrm{Xyl}$ and Fuc showed similar mean concentrations of 0.13 and $0.16 \mu \mathrm{mol}$ monomer equivalent $\mathrm{L}^{-1}$, respectively. In the late post-bloom period, Man/Xyl strongly increased, while Fuc decreased rapidly. Rha and Ara showed comparatively low concentrations $\leq 0.1 \mu \mathrm{mol} \mathrm{L}{ }^{-1}$ throughout the investigation period.

The acidic sugar GalUA was a major component of tCCHO before the onset of the bloom in February, followed by strongly declining concentrations in March (Figure 2C). Concentrations increased again until the end of the phytoplankton bloom, reaching values of $0.2-0.3 \mu \mathrm{mol} \mathrm{L} \mathrm{L}^{-1}$, comparable to the concentrations of most neutral sugars, in April (Figure 2C). The other acidic sugars GlcA, Mur, and GlcUA were only present in very low concentrations (below $0.02 \mu \mathrm{mol} \mathrm{L}^{-1}$ ). Of those, only GlcUA increased slightly in concentration toward the end of the bloom and maintained an elevated level during the postbloom. Amino sugars were only present at low concentrations (below $0.1 \mu \mathrm{mol} \mathrm{L}^{-1}$ ) (Figure 2D). However, both, GalN and GlcN concentrations increased toward the end of the bloom, with
GlcN reaching values of up to $0.07-0.08 \mu \mathrm{mol} \mathrm{L}^{-1}$, higher than the concentrations of most acidic sugars during the late bloom and post-bloom phases.

\section{Bacterial Community Composition}

Particle-associated and FL bacterial communities were significantly different during the post-bloom phase (PERMANOVA; $p=0.008,400$ permutations) but were similar during the pre-bloom (PERMANOVA; $p=0.092,10$ permutations) and bloom phases (PERMANOVA; $p=0.141$, 414 permutations). Both, PA and FL bacterial community significantly changed between phytoplankton bloom phases (PERMANOVA; $p=0.003,992$ permutations and $p<0.001$; 999 permutations, respectively), revealing distinct temporal successions. DistLM shows that the development of PA communities is significantly related to three environmental variables. Apart from an abrupt change along a POC gradient (explaining $\sim 31 \%$ of total community variability) at the onset of the phytoplankton bloom, PA bacteria showed the strongest community development during the post-bloom phase, following a gradient of temperature (explaining $\sim 20 \%$ ) and carbohydrates (colCHO, explaining 9\%) (Table 1, Figure 3). The FL bacterial community composition strongly changed during the ongoing phytoplankton bloom and during the post-bloom phase, mainly tracking with diatom abundance 
A

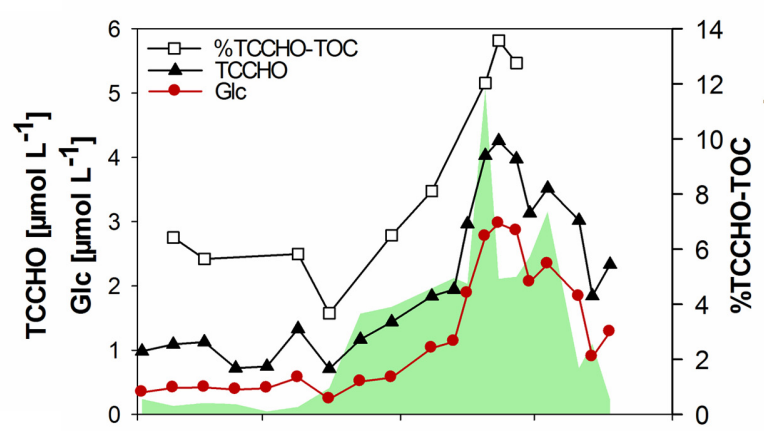

C

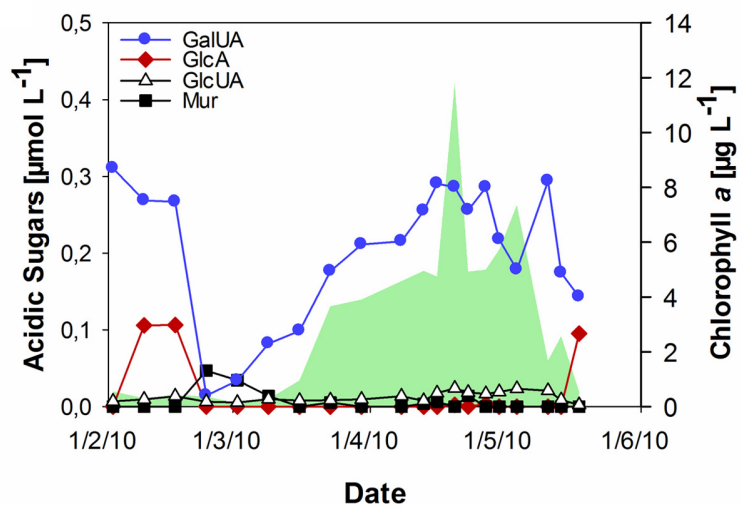

B

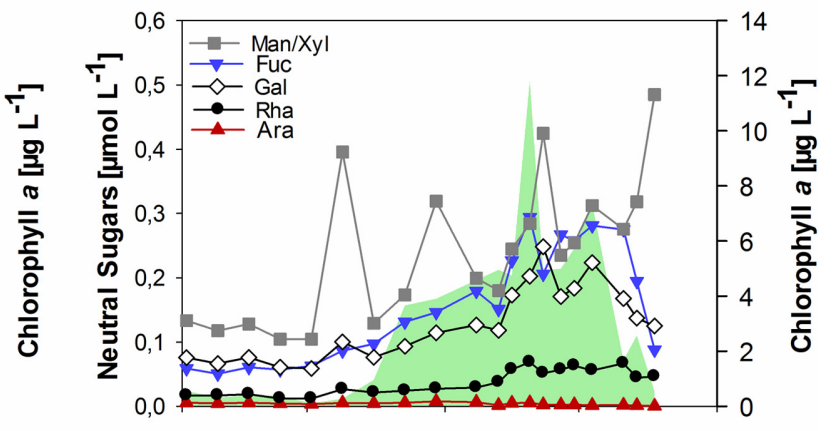

D

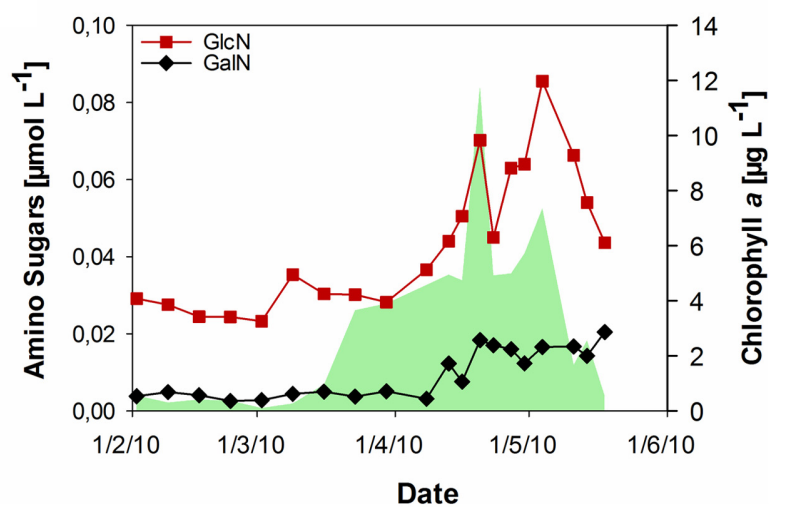

FIGURE 2 | Concentrations of combined carbohydrates $>\mathbf{1} \mathbf{k D a}$ (TCCHO) during the spring bloom. (A) Concentrations of TCCHO and combined glucose (Glc) and share of TCCHO in TOC (\% TCCHO-TOC, TOC = POC + DOC) (B) Concentrations of neutral sugars including mannose/xylose (Man/Xyl), fucose (FuC), galactose (Gal), rhamnose (Rha), and arabinose (Ara) (C) Concentrations of acidic sugars including gluconic acid (GlcA), glucuronic acid (GlcUA), galacturonic acid (GalUA), and muramic acid (Mur) (D) Amino sugars including glucosamine (GlcN) and galactosamine (GalN). The green shaded area represents concentrations of chlorophyll a.

$(\sim 14 \%)$ and temperature $(\sim 34 \%)$, respectively (Table $\mathbf{1}$, Figure 3). In total, significant environmental factors explained $\sim 60$ and $\sim 48 \%$ of the variability in PA and FL communities, respectively. The richness of PA bacteria increased with rising Chl $a$ and tCCHO concentrations, revealing a linear correlation $\left(R^{2}=0.3779, p=0.0093\right)$ between colCHO concentration and PA bacterial richness (Supplementary Figure S1). The PA richness reached a maximum approximately 1.5 weeks after the breakdown of the bloom at persistently high concentrations of tCCHO and was followed by a steep decrease in both richness and tCCHO thereafter (Figures 2A and 4). In contrast, the richness of FL bacteria did not resemble the temporal development of $\mathrm{Chl} a$ or diatom cell numbers during the bloom (Figure 4).

Of the investigated microbial clades (CARD-FISH), only GAM42 (Gammaproteobacteria) showed a direct positive correlation to colCHO and to GalUA (Supplementary Table S3). Notably, these also correlated to temperature and $\mathrm{pH}$, as well as POC and Chl $a$. Furthermore, they were correlated positively to all investigated extracellular enzymes. Although in total, Roseobacter did not correlate to any investigated parameter, the SAR11 subgroup correlated to $\mathrm{pH}$ and silicate. Bacteroidetes correlated to $\mathrm{Chl} a$.

\section{Extracellular Enzyme Activity}

The activity of extracellular enzymes was near the detection limit from February to mid-March (Figure 5). With the onset of the phytoplankton bloom, leucine-aminopeptidase (LAPase) activity increased and maintained high levels during the bloom, reaching a maximum of $0.95 \mu \mathrm{mol} \mathrm{L} \mathrm{L}^{-1} \mathrm{~h}^{-1}$ in the postbloom phase. The activity of $\beta$-glucosidase $(\beta$-Glcase) increased toward the end of the bloom, concurrent with a strong increase in tCCHO concentrations (Figure 2A). A maximum rate of $0.08 \mu \mathrm{mol} \mathrm{L} \mathrm{L}^{-1} \mathrm{~h}^{-1}$ was determined on May 11th. The amount of substrate hydrolyzed by $\beta$-Glcase during the post-bloom phase was estimated as approximately $2.16 \mu \mathrm{mol}$ $\mathrm{L}^{-1}$, equivalent to approximately $72 \%$ of the total combined glucose that accumulated during the bloom (Figure 2A). The rates of extracellular phosphatase (phos), increased rapidly after phosphate depletion (Figures 1D and 5) at the end of the bloom, indicating the enhanced use of organic phosphorous by bacteria and phosphatase-releasing phytoplankton groups. The co-incidence of phosphate depletion with a pronounced increase in phosphatase activity correlates well with the increase in phosphate transporters, as reported in Teeling et al. (2012) for the year 2009. This implies that the enzymatic degradation 
TABLE 1 | DistLM showing the correlation of ARISA-band-diversity (Sørensen) to environmental factors (sequential addition to the model).

\begin{tabular}{lccccc}
\hline Variable & Adj. $\boldsymbol{R}^{2}$ & Pseudo- $\boldsymbol{F}$ & $\boldsymbol{P}$ & Prop. \% & Cumul. \% \\
\hline Particle-associated & & & & & \\
POC & 0.26115 & 59.48 & $\mathbf{0 . 0 0 1}$ & 31.39 & 31.39 \\
Temp & 0.42877 & 48.15 & $\mathbf{0 . 0 0 6}$ & 19.65 & 51.04 \\
colCHO & 0.49407 & 25.49 & $\mathbf{0 . 0 0 9}$ & 9.21 & 60.25 \\
pH & 0.52738 & 17.76 & 0.075 & 5.99 & 66.24 \\
Diatoms & 0.55793 & 1.69 & 0.104 & 5.34 & 71.58 \\
Sal & 0.58148 & 15.06 & 0.169 & 4.50 & 76.08 \\
DIN & 0.60484 & 1.47 & 0.200 & 4.16 & 80.24 \\
Ara & 0.63418 & 15.61 & 0.194 & 4.08 & 84.32 \\
Mur-A & 0.66667 & 1.59 & 0.213 & 3.77 & 88.10 \\
Chl & 0.70459 & 16.42 & 0.221 & 3.46 & 91.56 \\
Free-living & & & & & \\
Temp & 0.29753 & 82.00 & $\mathbf{0 . 0 0 1}$ & 33.89 & 33.89 \\
Diatoms & 0.40907 & 40.20 & $\mathbf{0 . 0 0 1}$ & 13.98 & 47.86 \\
PO4 & 0.42655 & 14.57 & 0.181 & 4.92 & 52.78 \\
Chl & 0.46659 & 2.05 & 0.073 & 6.44 & 59.21 \\
Sal & 0.47932 & 13.18 & 0.27 & 4.04 & 63.25 \\
colCHO & 0.5011 & 15.24 & 0.175 & 4.47 & 67.72 \\
POC & 17.71 & 0.13 & 4.86 & 72.58 \\
\hline Signicant & 0.53377 & & & &
\end{tabular}

Significant variables $(p<0.05)$ are given in bold.

of organic phosphorous was repressed by the accumulation of its end product.

All enzyme activities were positively correlated with seawater $\mathrm{pH}$, temperature and POC but were negatively correlated to nutrients (Table 2). Phos was positively correlated to DOC. In general, all neutral tCCHO except Ara and Man/Xyl showed strong $\left(r_{\mathrm{s}}>0.7\right)$ to very strong $\left(r_{\mathrm{s}}>0.9\right)$ positive correlations with LAPase, Glcase, and phos. Furthermore, amino sugars correlated well with enzyme activities. $\beta$-Glcase and LAPase activity were very strongly $\left(r_{\mathrm{s}}>0.9\right)$ correlated with Fuc, while LAPase was correlated very strongly $\left(r_{\mathrm{s}}>0.9\right)$ with Gal. Man/Xyl correlated with only amino-peptidase and phos, but not $\beta$-Glcase. The amino-sugars correlated well with enzyme activities. GlcURA was the only acidic sugar showing a significant correlation with enzyme activities.

\section{DISCUSSION}

The present study is the first field study combining a detailed analysis of the monomeric composition of polysaccharides in seawater with an investigation of bacterial community composition and the activity of hydrolytic extracellular enzymes. Multivariate statistics were applied to investigate the relationship between the temporal development of the bacterioplankton community and environmental parameters during the spring bloom. Correlations cannot prove or disprove functional relationships but are a valuable measure of the relevance of certain environmental controls on communities and activities. The discussion addresses the temporal development of carbohydrate composition, bacterioplankton community composition and enzyme activities. Furthermore, it aims to

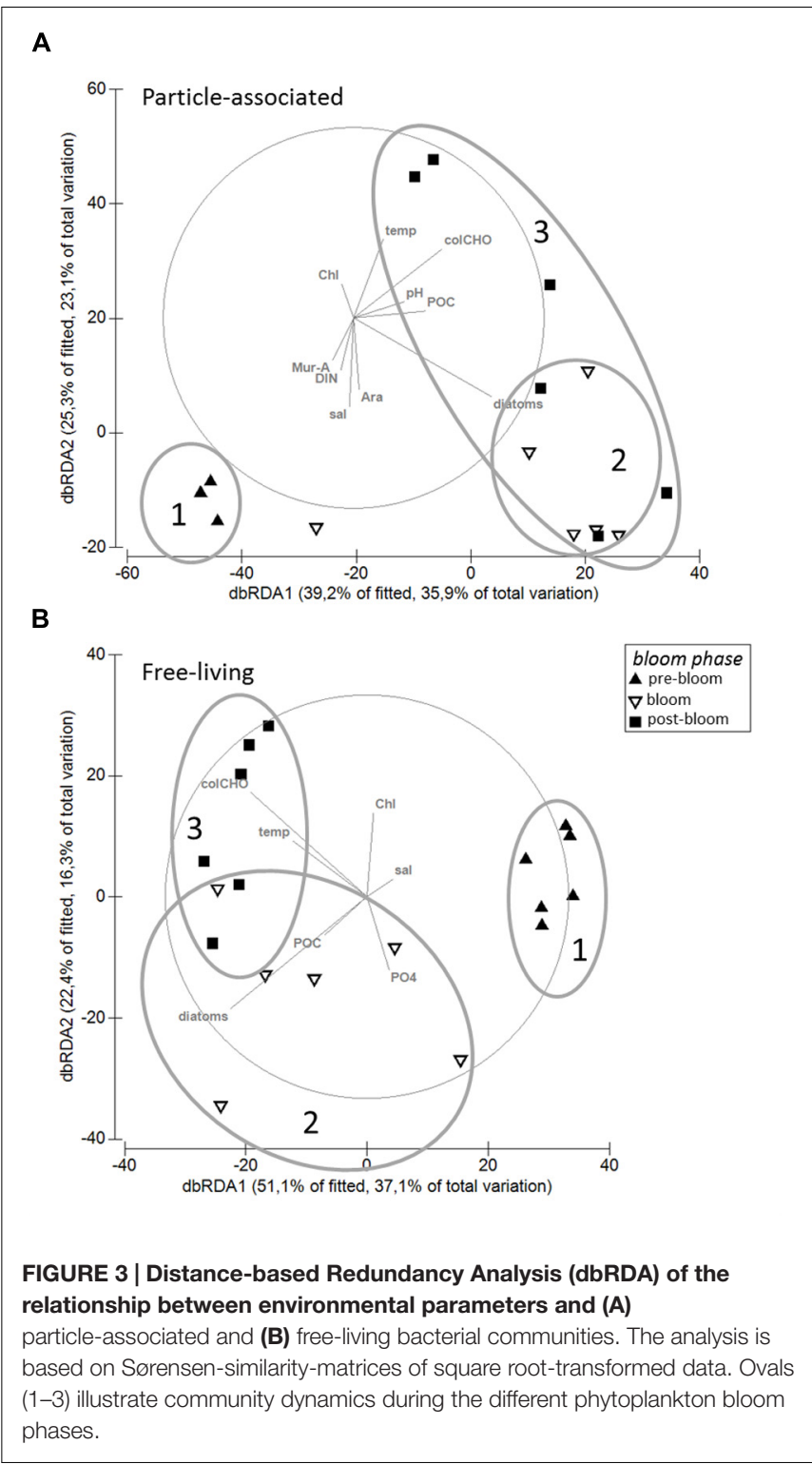

reveal potential links between the succession of bacterioplankton and major abiotic and biotic factors during the spring bloom at Helgoland Roads.

\section{The Contribution of Combined Carbohydrates to Organic Matter during Phytoplankton Bloom Development}

Phytoplankton spring blooms are events of high OM input into marine systems. The diatom spring bloom investigated at Helgoland Roads in 2010 showed a maximum Chl

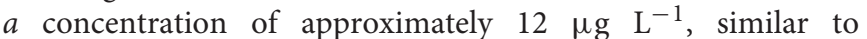
concentrations reported for the southern North Sea (Veldhuis et al., 1986) but twofold lower than at Helgoland Roads in 2009 (Teeling et al., 2012). The investigated bloom sustained an average POC concentration of $29 \mu \mathrm{mol} \mathrm{C} \mathrm{L}{ }^{-1}$, well within the range observed previously in the German Bight (Rink 


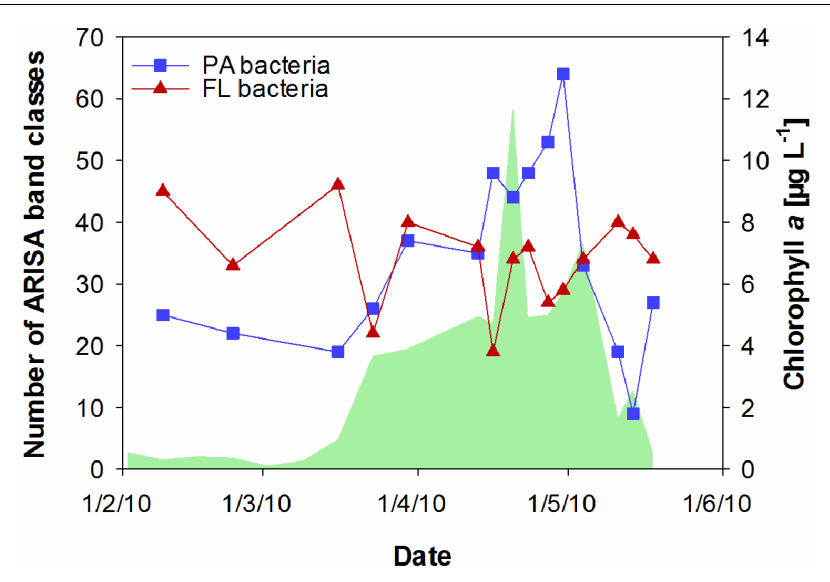

FIGURE 4 | Temporal changes in the richness of particle-associated (PA) bacteria and free-living (FL) bacteria at Helgoland Roads, derived from ARISA band classes. The green shaded area represents concentrations of chlorophyll a.

et al., 2011) and comparable to values found in springtime in the eastern North Atlantic (Engel et al., 2012). Average DOC

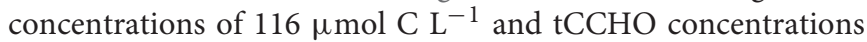
of $2 \mu \mathrm{mol}$ monomer equivalent $\mathrm{L}^{-1}$ determined in our study are approximately $30 \%$ higher than in the eastern North Atlantic Ocean (Engel et al., 2012). The contribution of tCCHO to TOC at Helgoland Roads averaged $8.3 \%$, similar to the percentage of neutral sugars in the TOC of the NW-Mediterranean Sea in April (Jones et al., 2013) but approximately fourfold higher than at the oligotrophic Bermuda Atlantic Time-Series station (BATS) in June (Kaiser and Benner, 2009). The results of this study reveal collinear temporal dynamics of most monomeric components in combined carbohydrates (colCHO) during the growth and decline of the diatom spring bloom at Helgoland Roads. The carbohydrate composition was dominated by high shares of combined glucose. The molar percentages of the individual neutral sugars in $\mathrm{tCCHO}$ are more similar to the carbohydrate composition in Oregon inshore waters and Arctic waters than to the carbohydrate composition in the equatorial Pacific Ocean or the Sargasso Sea (Borch and Kirchman, 1997; Rich et al., 1997; Kirchman et al., 2001).

The contribution of tCCHO to TOC increased strongly during the late bloom phase. The coincidence of increasing tCCHO concentrations and the depletion of dissolved inorganic phosphorous and dissolved silicate suggests that enhanced phytoplankton exudation substantially contributed to the production of carbohydrate-rich OM. Laboratory studies have shown that large diatom species, in particular, release high amounts of carbohydrate-rich exudates when grown under nutrient-limited conditions (Engel et al., 2002; Passow, 2002). Diatom exudates are important precursors for the formation of marine particles. Exuded polysaccharidic gels, like transparent exopolymeric particles (TEP), provide surfaces for bacterial colonization and subsequent degradation. Furthermore, TEP play a decisive role in the formation of macroscopic aggregates that promote flocculation and sinking of biogenic material at the end of bloom events (Passow et al., 1994). Acidic sugars represent a substantial fraction of carbohydrates in TEP (Alldredge et al., 1993; Mopper et al., 1995; Passow, 2002). GalUA and GlcUA, the two acidic sugars analyzed in this study, showed very different temporal developments. While concentrations of GlcUA increased only slightly in the post-bloom phase, strong increases in GalUA coincided with rising Chl $a$ concentrations. This accumulation of GalUA during the bloom supports the assumption of a high proportion of exudates derived from phytoplankton at Helgoland Roads. In addition to exudation, grazing has potentially contributed to the release of dissolved carbohydrates. The relatively low $\mathrm{Chl} a$ concentrations recorded in our study indicate a top-down control of phytoplankton by

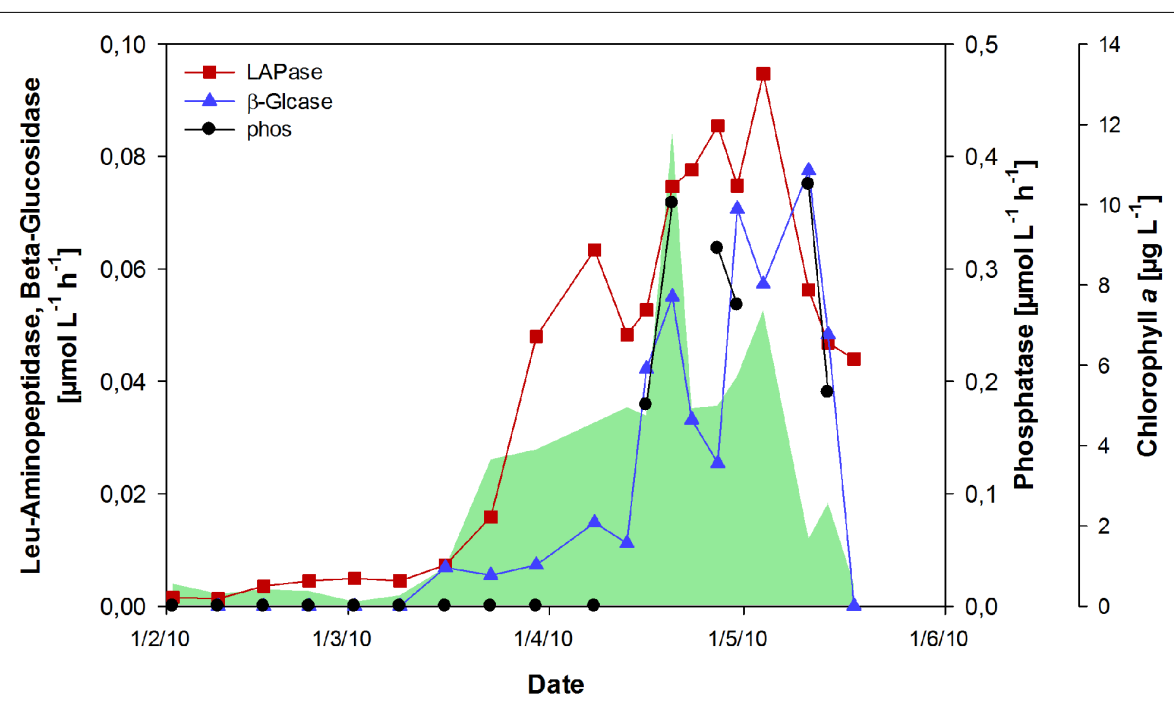

FIGURE 5 | Activity of hydrolytic extracellular enzymes during the spring bloom. Rates for leucine (Leu)-aminopeptidase (LAPase), $\beta$-glucosidase ( $\beta$-Glcase), and phosphatase (phos) are shown. The green shaded area represents concentrations of chlorophyll a. 
TABLE 2 | Spearman correlation $(p<0.05)$ of different carbohydrates and environmental factors to extracellular enzyme activity of $\beta$-glucosidase ( $\beta$-Glcase), leucine amino peptidase (LAPase), and phosphatase (phos).

\begin{tabular}{|c|c|c|c|}
\hline & $\beta$-Glcase & LAPase & phos \\
\hline \multicolumn{4}{|c|}{ Carbohydrates } \\
\hline Ara & $\varnothing$ & $\varnothing$ & - \\
\hline Fuc & +++ & +++ & ++ \\
\hline Gal & ++ & +++ & ++ \\
\hline Glc & ++ & ++ & ++ \\
\hline Man/Xyl & $\varnothing$ & + & + \\
\hline Rha & ++ & ++ & ++ \\
\hline GalAM & + & + & ++ \\
\hline GlcAM & ++ & ++ & ++ \\
\hline GlcA & $\varnothing$ & $\varnothing$ & $\varnothing$ \\
\hline MurA & $\varnothing$ & $\varnothing$ & $\varnothing$ \\
\hline GalURA & $\varnothing$ & $\varnothing$ & $\varnothing$ \\
\hline GlcURA & + & + & + \\
\hline \multicolumn{4}{|c|}{ Environmental parameters } \\
\hline $\mathrm{pH}$ & ++ & ++ & ++ \\
\hline SECCI & - & $\varnothing$ & $\varnothing$ \\
\hline Temp & ++ & ++ & ++ \\
\hline Sal & - & - & -- \\
\hline $\mathrm{SiO}_{2}$ & -- & -- & -- \\
\hline $\mathrm{PO}_{4}$ & - & - & - \\
\hline $\mathrm{NO}_{2}$ & -- & -- & -- \\
\hline Diatoms & + & ++ & $\varnothing$ \\
\hline Chla & ++ & ++ & + \\
\hline DOC & $\varnothing$ & $\varnothing$ & ++ \\
\hline $\mathrm{POC}$ & +++ & +++ & ++ \\
\hline
\end{tabular}

zooplankton (Lohmann and Wiltshire, 2012) that tends to lead to a release of complex carbohydrates from sloppy feeding (Storm et al., 1997).

The complex DOM released from phytoplankton is highly strain specific (Becker et al., 2014) and likely explains most of the associations of specific plankton bacteria with particular phytoplankton strains (e.g., Hahnke et al., 2013). Phytoplanktonderived polysaccharides have been shown to support cladespecific proliferation of bacterioplankton (Taylor et al., 2014). However, the species richness of heterotrophic bacteria is higher than that of autotrophs, suggesting a complex but not strictly species-related interaction between phytoplankton-derived OM and heterotrophic bacterioplankton. This is supported by the finding that relatively few strains of heterotrophic bacteria are associated with distinct phytoplankton communities (Teeling et al., 2016) and that most OM is used by generalists (Rink et al., 2007).

\section{Succession of Bacterioplankton}

A strong increase in almost all sugars in $\mathrm{tCCHO}$ toward the end of the bloom suggests an increase in ecological niches available to heterotrophic bacteria (Alonso-Sáez and Gasol, 2007; Teeling et al., 2012; Gifford et al., 2013). Indeed, a rapid increase in the richness of the PA bacterial community (approximately 50\%) was observed within the 14 days after diatom cell numbers peaked. In that period, the concentration of colCHO (the combined concentration of collinear sugars) was a significant factor impacting the succession of the PA bacterial community. Our results suggest that the influence of carbohydrate concentration on bacterial growth and activity observed earlier (e.g., Borch and Kirchman, 1997; Rich et al., 1997; Piontek et al., 2011) might be induced by not only increasing metabolic rates at the cellular level but also changes in bacterial communities toward efficient carbohydrate degradation. A previous study conducted during the spring bloom at Helgoland Roads showed the taxonomically distinct expression of TonB-dependent transporters, implying the specialization of populations for the successional degradation of carbohydrates in different size ranges (Teeling et al., 2012). Recruitment of FL bacteria to particles cannot explain the rise in PA richness during the post-bloom phase, as PA and FL communities were very similar throughout the phytoplankton bloom. Hence, organic particles rich in carbohydrates provide beneficial niches for a distinct and diverse PA bacterial community that sustains high rates of hydrolytic enzyme activity. Furthermore, approximately three times more new ARISA band classes were detected during the post-bloom phase than $\mathrm{tCCHO}$ components rise in concentration. This suggests that only part of the rise in richness could be explained by specialists growing on specific monomeric carbohydrates. It seems likely that several bacterial taxa thrive on the same component or use a specific combination of different components.

Our CARD-FISH analysis, which did not distinguish between $\mathrm{PA}$ and FL fractions, revealed that Gammaproteobacteria (GAM42) were positively correlated to colCHO and showed higher abundances toward the end of the bloom. Further correlations of Gammaproteobacteria with POC and Chl $a$ underline the importance of fresh OM derived from phytoplankton production for the growth of this group, which is a prominent member of bacterial communities associated with marine particles (Bižić-Ionescu et al., 2014). For the first time, this study shows that the abundance of Gammaproteobacteria is not only related to bulk OM but also to a specific OM component. TCCHO are considered a labile to semi-labile source of organic carbon, with turnover times ranging from days to months depending on molecular weight and structure. GAM42 is also correlated positively to $\beta$-Glcase, LAPase, and Phos in our study, indicating an active role in the enzymatic hydrolysis of organic particles and thereby in the transfer of carbon from the particulate to the dissolved pool.

Changes in community composition related to the concentrations of combined carbohydrates and POC during the post-bloom phase strongly suggest a partially substratecontrolled succession. Overall, the investigated factors in our study explain approximately 60 and $48 \%$ of the community variability in PA and FL bacterioplankton, respectively. Interestingly, the carbohydrate composition determined in this study does not explain the succession of bacterial communities, inferred from ARISA and CARD-FISH analysis, during the period of strongly rising $\mathrm{Chl} a$ concentrations (March 16th-April 20th, 2010). In addition, approximately $75 \%$ of PA ARISA band classes did not correlate with the development of carbohydrate 
concentrations in any bloom phase. This might be explained by the fact that carbohydrates analyzed in this study are $>1 \mathrm{kDa}$ and thus part of the HMW-OM. The most labile fraction of freshly produced OM includes LMW compounds, which were shown to strongly affect bacterial community composition in in vitro experiments (Gómez-Consarnau et al., 2012). It can be suggested that freshly produced LMW-OM, which is not included in our analysis, had a stronger influence on bacterial community structure during earlier bloom phases before HMW-OM began to accumulate. In addition to the factors POC, colCHO and diatom abundance (related to phytoplankton productivity), temperature had a significant effect on the composition of bacterioplankton, indicating a multifactorial environmental control of bacterioplankton by seasonal changes. In line with previous findings, FL bacteria, which are more directly exposed to conditions in the water body, were found to be susceptible to temperature changes during spring bloom development (Sapp et al., 2007). Accordingly, the FL bacterial community richness is less dynamic than the PA community, and no correlation to the composition or concentration of tCCHO was observed. Furthermore, the hydrographic history of the water mass should be considered as an important factor in shaping bacterioplankton communities. The abundance of SAR11, which constituted up to $40 \%$ of total bacterial cells in this study, is related to salinity changes in the southern North Sea that track with the dynamics of water masses (Sperling et al., 2012). Hence, the origin and trajectories of water masses can affect temporal developments observed in time series studies, if complex current patterns, such as those in the shallow southern North Sea prevail.

\section{Activity of Hydrolytic Extracellular Enzymes}

Extracellular enzyme activities were dependent on the phytoplankton bloom phase and were correlated to Chl $a, \mathrm{POC}, \mathrm{pH}$ and temperature. Enzymatic rates show positive correlations to the fluorescence intensity of many PA ARISA band classes that can serve as a semi-quantitative measure of the abundances of individual bands (Supplementary Figure S2). In addition, the high activity of extracellular $\beta$-Glcase was observed well after the Chl $a$ and tCCHO peaks, when PA bacterial richness was high. This indicates that for $\beta$-Glcase, high PA bacterial richness facilitates the enzymatic turnover of tCCHO. It is likely that the richer PA bacterial community produces not only high amounts of $\beta$-Glcase but also a high diversity of $\beta$-Glcase isoenzymes (Arrieta and Herndl, 2002), thereby further enhancing the efficiency of carbohydrate hydrolysis. A study analyzing annotated prokaryotic genomes revealed that the capacity to produce extracellular enzymes varies at fine-scale phylogenetic resolution (Zimmerman et al., 2013). In line with previous studies, it can be suggested that PA bacteria are the main producers of extracellular enzymes, as they are closer to their substrates or even reside in semi-enclosed environments where they profit from the effort of producing extracellular enzymes. In contrast, FL bacteria do not appear to invest as much in extracellular enzymes, but preferentially consume carbohydrates that are suitable for direct uptake and, in some cases, subsequent hydrolysis (Teeling et al., 2016).

The rates of $\beta$-Glcase determined in the post-bloom phase are sufficiently high to drive the observed loss of tCCHO during this late bloom stage. In late April, a maximum tCCHO amount of approximately $4 \mu \mathrm{mol} \mathrm{L} \mathrm{L}^{-1}$ accumulated and was subsequently reduced by $2 \mu \mathrm{mol} \mathrm{L}^{-1}$ during the post-bloom phase. This loss of tCCHO matches well with $\beta$-Glcase activity integrated over the post-bloom phase, which could sustain the hydrolytic release of $2.16 \mu \mathrm{mol} \mathrm{Glc} \mathrm{L}^{-1}$ within the 26 days of the post-bloom phase. In accordance with an earlier study (Arrieta and Herndl, 2002), high rates of extracellular $\beta$-Glcase were maintained even after the decline in bacterial richness. This can be explained by prolonged half-lives for excreted enzymes, in the range of days-weeks (Steen and Arnosti, 2011). The decay of the phytoplankton bloom did not result in increased FL bacterial richness, and only a few correlations of FL ARISA band classes to extracellular enzymes were found. This is in accordance with an earlier study that found no increased abundance of carbohydrate-active enzymes during post-phytoplankton spring blooms in FL bacteria at the same sampling site (Teeling et al., 2016). Therefore, it can be suggested that PA and FL bacteria mainly thrive on different forms of carbohydrates, and FL bacteria potentially profit from the pre-hydrolyzed substrates released from particles.

Little is known about the bioavailability of specific carbohydrates in seawater for heterotrophic marine bacterioplankton in situ. In our study, high concentrations of Glc, Fuc and Gal were associated with high PA bacterial diversity. Concentrations of these sugars in tCCHO clearly decreased during the postbloom phase, suggesting preferential degradation via bacterial activity. This observation partly corroborates findings from the Bay of Biscay, which also indicated Fuc and Gal to be actively consumed CHO. In contrast, Glc appears to be very actively processed during our study, but less dynamic in the Bay of Biscay (Engel et al., 2012). The availability of monomeric and oligomeric sugars for bacterioplankton consumption is, to a large extent, dependent on the degradability of preceding polymers. A Bacteroidetes isolate from North Sea surface waters, Gramella forsetii KT0803, showed polymerspecific transcription of polysaccharide utilization loci (PULs) for laminarin and alginate that comprised genes of surfaceexposed proteins such as oligomer transporters, substratebinding proteins, and carbohydrate-active enzymes (Kabisch et al., 2014). In particular, laminarin is a widespread polymer in the ocean that is found as a storage glucan in diatoms and brown algae, among others. It consists of glucose monomers linked by $\beta$-glycosidic bonds that can be hydrolyzed by $\beta$-Glcase. Its homopolysaccharidic structure (i.e., consisting of only one type of monomer) further facilitates efficient hydrolysis by exo-enzymes. Homopolysaccharides have been found to be preferentially utilized over heteropolysaccharides (Amon and Benner, 2003). Heteropolysaccharides consisting of Rha, Fuc, Xyl, Man, and Gal are mainly part of the cell wall (Alderkamp et al., 2007) and are excreted as extracellular polymeric substances (Hama and Yanagi, 2001). Both glucanes and heteropolysaccharides appear to contribute to the rise in carbohydrates observed during the bloom in 
our study. Apart from Glc in glucanes, Fuc and Gal appear to be part of labile polymers. In addition to the monomeric composition of polysaccharides, also the molecule structure of the substrate has been shown to co-determine the accessibility to extracellular enzymes (Pantoja and Lee, 1999; Arnosti, 2000, 2004). Laminarinase enzymes, for example, showed minimal activity on substrates, with similar glucosidic bonds to those of laminarin, but different sizes and secondary and/or tertiary structures, revealing that the hydrolysis rates among substrates of similar sizes but differing structures can vary considerably (Alderkamp et al., 2006). Overall, it can be assumed that the metabolic capacities of the bacterial community adapted to the chemical properties of available polysaccharides, resulting in efficient polysaccharide degradation during the spring bloom at Helgoland Roads.

\section{CONCLUSION}

The present study shows a correlation between the concentration of combined carbohydrates in HMW-OM and the diversity of PA bacteria during the development of a spring bloom, suggesting that the availability of carbohydrates contributes to the multifactorial control of marine bacterioplankton communities. Our study is in line with earlier findings demonstrating the importance of PA bacteria for total community activity (Alldredge and Silver, 1988; Herndl, 1988; Grossart et al., 2006b; Lyons and Dobbs, 2012). This highlights the additional value of analyzing bacterioplankton community composition in size-fractionated samples. As inferred from decreasing concentrations during the post-bloom phase, glucose, fucose, and galactose were preferentially utilized sugars in HMWOM. There is growing evidence that phytoplankton primary production and $\mathrm{OM}$ release is susceptible to ocean change. Climate models project the shoaling of upper mixed layer depth as a consequence of sea-surface warming. Changes in the mixed layer depth can affect primary production and the timing of spring blooms and thus the pool of OM that is subject to bacterial remineralization. A mesocosm study further showed that phytoplankton growth under increasing temperature accelerates carbohydrate accumulation (Engel et al., 2011). In addition to warming, the dissolution of increasing anthropogenic $\mathrm{CO}_{2}$ in seawater, referred to as ocean acidification, can significantly affect phytoplankton productivity. A mesocosm experiment revealed that elevated $\mathrm{pCO}_{2}$ increased primary production in Arctic plankton communities (Engel et al., 2013). In the same experiment, the PA bacterial community richness was shown to be higher in mesocosms at elevated $p \mathrm{CO}_{2}$ (Sperling et al., 2013). Increasing exudation has been suggested as a physiological strategy for Emiliania huxleyi, a bloom-forming coccolithophore, to grow under a condition of elevated $\mathrm{pCO}_{2}$ and low nutrient availability (Borchard and Engel, 2012). Combining results from fieldwork and experiments, it can be suggested that carbohydrates, the primary product of photosynthesis, have high potential to mediate the effects of ocean change on bacterioplankton community structure and function (Supplementary Figure S3).

\section{AUTHOR CONTRIBUTIONS}

MS developed the study concept and conducted the sampling as well as most of the sample- and data analysis. He also wrote the manuscript. JP helped develop the study concept, provided methodological support, especially with acquisition and analysis of extracellular enzyme data, and contributed to the manuscript. $\mathrm{AE}$ and $\mathrm{AW}$ provided lab space and financial and methodological support, helped develop the study concept and contributed to the manuscript. KW provided phytoplankton- and physicochemical data and contributed to the manuscript. JN provided data on dissolved organic carbon and contributed to the manuscript. GG provided lab space and financial and methodological support, helped develop the study concept, supported the statistical analysis and contributed to the manuscript.

\section{FUNDING}

The German Federal Ministry of Education and Research (BMBF) supported this study by funding the Microbial Interactions in Marine Systems project (MIMAS, project 03F0480A, http://mimas-project.de). Financial support for MS was provided through a stipend by the Helmholtz Graduate School for Polar and Marine Research (POLMAR).

\section{ACKNOWLEDGMENTS}

The authors would like to thank the crews of the research vessels "Aade" and "Diker" at the Biological Institute Helgoland. We also like to thank Hilke Döpke and Mirja Meiners for help with sample preparation and laboratory work. We thank Niels Moritz for the dialysis/hydrolysis of the carbohydrate samples, Jon Roa for the analyses, Christiane Lorenzen for the POC analysis and Matthias Friebe for the DOC analysis. We thank Bernhard M. Fuchs for valuable contributions to the manuscript. We also thank the reviewers GG and JF for improvements to the manuscript.

\section{SUPPLEMENTARY MATERIAL}

The Supplementary Material for this article can be found online at: $\quad$ http://journal.frontiersin.org/article/10.3389/fmicb.2017. 00065/full\#supplementary-material

FIGURE S1 | Richness of particle-associated (3-10 $\mu \mathrm{m})$ bacterioplankton vs. the concentration of colCHO $\left(R^{2}=0.3779, p=0.0093\right)$.

FIGURE S2 | Percent of particle-associated and free-living ARISA band classes (fluorescence intensity) correlating (Spearman Rank Correlation; $\left.r_{\mathrm{s}}>0.5, p<0.05\right)$ to the maximum velocity $\left(V_{\max }\right)$ of the extracellular enzymes $\beta$-glucosidase ( $\beta$-Glcase), leucine aminopeptidase (LAPase) and phosphatase (phos) during spring 2010 at the Helgoland Roads sampling station.

FIGURE S3 | Schematic representation of a mechanism for secondary effects of ocean change on bacterioplankton community and activity.

TABLE S1 | Analyzed carbohydrates and abbreviations. 
TABLE S2 | Concentrations of tCCHO components in $\mathrm{nmol} \mathrm{L}^{-1}$.

TABLE S3 | Spearman correlation $(p<0.05)$ of FISH-counts to environmental factors (abiotic and biotic), concentrations of selected carbohydrates, and extracellular enzyme activities of $\beta$-glucosidase

\section{REFERENCES}

Alderkamp, A.-C., Buma, A. G. J., and van Rijssel, M. (2007). The carbohydrates offf Phaeocystis and their degradation in the microbial food web. Biogeochemistry 83, 99-118. doi: 10.1007/s10533-007-9078-2

Alderkamp, A.-C., Sintes, E., and Herndl, G. J. (2006). Abundance and activity of major groups of prokaryotic plankton in the coastal North Sea during spring and summer. Aquat. Microb. Ecol. 45, 237-246. doi: 10.3354/ame045237

Alldredge, A. L., Pasow, U., and Logan, B. E. (1993). The abundance and significance of a class of large, transparent organic particles in the ocean. Deep Sea Res. 40, 1131-1140. doi: 10.1016/0967-0637(93)90129-Q

Alldredge, A. L., and Silver, M. W. (1988). Characteristics, dynamics and significance of marine snow. Prog. Oceanogr. 20, 41-82. doi: 10.1016/00796611(88)90053-5

Allgaier, M., Riebesell, U., Vogt, M., Thyrhaug, R., and Grossart, H.-P. (2008). Coupling of heterotrophic bacteria to phytoplankton bloom development at different pCO2 levels: a mesocosm study. Biogeosciences 5, 1007-1022. doi: 10.5194/bg-5-1007-2008

Alonso-Sáez, L., and Gasol, J. M. (2007). Seasonal variations in the contributions of different bacterial groups to the uptake of low-molecular-weight compounds in Northwestern mediterranean coastal waters. Appl. Environ. Microbiol. 73, 3528-3535. doi: 10.1128/AEM.02627-06

Amon, R. M. W., and Benner, R. (1996). Bacterial utilization of different size classes of dissolved organic matter. Limnol. Oceanogr. 41, 41-51. doi: 10.4319/lo.1996. 41.1.0041

Amon, R. M. W., and Benner, R. (2003). Combined neutral sugars as indicators of the diagenetic state of dissolved organic matter in the Arctic Ocean. Deep Sea Res. Part I 50, 151-169. doi: 10.1016/S0967-0637(02)00130-9

Arnosti, C. (2000). Substrate specificity in polysaccharide hydrolysis: contrasts between bottom water and sediments. Limnol. Oceanogr. 45, 1112-1119.

Arnosti, C. (2004). Speed bumps and barricades in the carbon cycle: substrate structural effects on carbon cycling. Mar. Chem. 92, 263-273. doi: 10.1016/j. marchem.2004.06.030

Arrieta, J. M., and Herndl, G. J. (2002). Changes in bacterial $\beta$-Glcase cosidase diversity during a coastal phytoplankton bloom. Limnol. Oceanogr. 47, 594-599. doi: 10.4319/lo.2002.47.2.0594

Azam, F., Fenchel, T., Field, J. G., Gray, J. S., Meyer-Reil, L. A., and Thingstad, T. F. (1983). The ecological role of water-column microbes in the sea. Mar. Ecol. Prog. Ser. 10, 257-263.

Becker, J. W., Berube, P. M., Follett, C. L., Waterbury, J. B., Chisholm, S. W., DeLong, E. F., et al. (2014). Closely related phytoplankton species produce similar suites of dissolved organic matter. Front. Microbiol. 5:111. doi: 10.3389/ fmicb.2014.00111

Bižić-Ionescu, M., Zeder, M., Ionescu, D., Orlić, S., Fuchs, B. M., Grossart, H.-P., et al. (2014). Comparison of bacterial communities on limnic versus coastal marine particles reveals profound differences in colonization. Environ. Microbiol. 17, 3500-3514. doi: 10.1111/1462-2920.12466

Borch, N. H., and Kirchman, D. L. (1997). Concentration and composition of dissolved combined neutral sugars (polysaccharides) in sewater determined by HPLC-PAD. Mar. Chem. 57, 85-95. doi: 10.1016/S0304-4203(97)00002-9

Borchard, C., and Engel, A. (2012). Organic matter exudation by Emiliania huxleyi under simulated future ocean conditions. Biogeosciences 9, 3405-3423. doi: 10.5194/bg-9-3405-2012

Brown, M. V., Schwalbach, M. S., Hewson, I., and Fuhrman, J. A. (2005). Coupling 16S-ITS rDNA clone libraries and automated ribosomal intergenic spacer analysis to show marine microbial diversity: development and application to a time series. Environ. Microbiol. 7, 1466-1479. doi: 10.1111/j.1462-2920.2005. 00835.x

Chróst, R. J. (ed.). (1991). Microbial Enzymes in Aquatic Environments. New York, NY: Springer.
( $\beta$-Glcase), leucine amino peptidase (LAPases) and phosphatase (phos).

$\varnothing=$ no significant correlation; $+=$ modest positive correlation $\left(r_{\mathrm{S}}>0.4\right)$, $++=$ strong positive correlation $\left(r_{\mathrm{s}}>0.7\right),+++=$ very strong positive correlation $\left(r_{\mathrm{s}}>0.9\right),-=$ modest negative correlation $\left(r_{\mathrm{s}}<-0.4\right),--=$ strong negative correlation $\left(r_{\mathrm{s}}<-0.7\right)$.

Cox, R., and Culkin, F. (1976). Sodium, potassium, magnesium, calcium and strontium in sea water. Deep Sea Res. 13, 789-804.

Elifantz, H., Malmstrom, R. R., Cottrell, M. T., and Kirchmann, D. L. (2005). Assimilation of polysaccharides and glucose by major bacterial groups in the delaware estuary. Appl. Environ. Microbiol. 71, 7799-7805. doi: 10.1128/AEM. 71.12.7799-7805.2005

Engel, A., Borchard, C., Piontek, J., Schulz, K. G., Riebesell, U., and Bellerby, R. (2013). CO2 Increases 14C primary production in an Arctic plankton community. Biogeosciences 10, 1291-1308. doi: 10.5194/bg-10-12912013

Engel, A., Goldthwait, S., Passow, U., and Alldredge, A. (2002). Temporal decoupling of carbon and nitrogen dynamics in a mesocosm diatom bloom. Limnol. Oceanogr. 47, 753-761. doi: 10.4319/lo.2002.47.3.0753

Engel, A., and Händel, N. (2011). A novel protocol for determining the concentration and composition of sugars in particulate and in high molecular weight dissolved organic matter (HMW-DOM) in seawater. Mar. Chem. 127, 180-191. doi: 10.1016/j.marchem.2011.09.004

Engel, A., Händel, N., Wohlers, J., Lunau, M., Grossart, H.-P., Sommer, U., et al. (2011). Effects of sea surface warming on the production and composition of dissolved organic matter during phytoplankton blooms: results from a mesocosm study. J. Plankton Res. 33, 357-372. doi: 10.1093/plankt/fbq122

Engel, A., Harlay, J., Piontek, J., and Chou, L. (2012). Contribution of combined carbohydrates to dissolved and particulate organic carbon after the spring bloom in the northern Bay of Biscay (North-Eastern Atlantic Ocean). Cont. Shelf Res. 45, 42-53. doi: 10.1016/j.csr.2012.05.016

Engel, A., Piontek, J., Grossart, H.-P., Riebesell, U., Schulz, K. G., and Sperling, M. (2014). Impact of CO2 enrichment on organic matter dynamics during nutrient induced coastal phytoplankton blooms. J. Plankton Res. 36, 641-657. doi: 10. 1093/plankt/fbt125

Gieskes, J. M. (1969). Effect of temperature on the pH of seawater. Limnol. Oceanogr. 14, 679-685. doi: 10.4319/lo.1969.14.5.0679

Gifford, S. M., Sharma, S., Booth, M., and Moran, M. A. (2013). Expression patterns reveal niche diversification in a marine microbial assemblage. ISME J. 7, 281-298. doi: 10.1038/ismej.2012.96

Gómez-Consarnau, L., Lindh, M. V., Gasol, J. M., and Pinhassi, J. (2012). Structuring of bacterioplankton communities by specific dissolved organic carbon compounds. Environ. Microbiol. 14, 2361-2378. doi: 10.1111/j.14622920.2012.02804.x

Grasshoff, K., Kremling, K., and Ehrhardt, M. (1999). Methods of Seawater Analysis. Weinheim: Wiley-VCH.

Grossart, H. P., Allgaier, M., Passow, U., and Riebesell, U. (2006a). Testing the effect of $\mathrm{CO} 2$ concentration on the dynamics of marine heterotrophic bacterioplankton. Limnol. Oceanogr. 51, 1-11. doi: 10.4319/lo.2006.51.1.0001

Grossart, H. P., Kiørboe, T., Tang, K. W., Allgaier, M., Yam, E. M., and Ploug, H. (2006b). Interactions between marine snow and heterotrophic bacteria: aggregate formation and microbial dynamics. Aquat. Microb. Ecol. 42, 19-26. doi: 10.3354/ame042019

Hahnke, S., Sperling, M., Langer, T., Wichels, A., Gerdts, G., Beardsley, C., et al. (2013). Distinct seasonal growth patterns of the bacterium Planktotalea fisia in the North Sea and specific interaction with phytoplankton algae. FEMS Microbiol. Ecol. 86, 185-199. doi: 10.1111/1574-6941.12151

Hama, T., and Yanagi, K. (2001). Production and neutral aldose composition of dissolved carbohydrates excreted by natural marine phytoplankton populations. Limnol. Oceanogr. 46, 1945-1955. doi: 10.4319/lo.2001.46.8.1945

Herndl, G. J. (1988). Ecology of amorphous aggregations (marine snow) in the Northern Adriatic Sea. 2. Microbial density and activity in marine snow and its implications to the overall pelagic processes. Mar. Ecol. Prog. Ser. 48, 265-275.

Hoppe, H.-G. (1983). Significance of exoenzymatic activities in the ecology of brackish water: measurements by means of methylumbelliferyl-substrates. Mar. Ecol. Prog. Ser. 11, 299-308. 
Hutchinson, G. E. (1961). The paradox of the plankton. Am. Nat. 95, 137-145. doi: $10.1086 / 282171$

Jones, V., Meador, T. B., Gogou, A., Migon, C., Penkman, K. E. H., Collins, M. J., et al. (2013). Characterisation and dynamics of dissolved organic matter in the Northwestern Mediterranean Sea. Prog. Oceanogr. 119, 78-89.

Kabisch, A., Otto, A., König, S., Becher, D., Albrecht, D., Schüler, M., et al. (2014). Functional characterization of polysaccharide utilization loci in the marine Bacteroidetes 'Gramella forsetii' KT0803. ISME J. 8, 1492-1502. doi: 10.1038/ ismej.2014.4

Kaiser, K., and Benner, R. (2009). Biochemical composition and size distribution of organic matter at the Pacific and Atlantic time-series stations. Mar. Chem. 113, 63-77. doi: 10.1016/j.marchem.2008.12.004

Kirchman, D. L., Meon, B., Ducklow, H. W., Carlson, C. A., Hansell, D. A., and Steward, G. F. (2001). Glucose fluxes and concentrations of dissolved combined neutral sugars (polysaccharides) in the Ross Sea and Polar Front Zone, Antarctica. Deep Sea Res. Partt II 48, 4179-4197. doi: 10.1016/S09670645(01)00085-6

Knefelkamp, B., Carstens, K., and Wiltshire, K. H. (2007). Comparison of different filter types onchlorophyll-a retention and nutrient measurements. J. Exp. Mar. Biol. Ecol. 345, 61-70. doi: 10.1016/j.jembe.2007.01.008

Kovacs, A., Yacoby, K., and Gophna, U. (2010). A systematic assessment of automated ribosomal intergenic spacer analysis (ARISA) as a tool for estimating bacterial richness. Res. Microbiol. 161, 192-197. doi: 10.1016/j.resmic.2010.01. 006

Krause, E., Wichels, A., Giménez, L., Lunau, M., Schilhabel, M. B., and Gerdts, G. (2012). Small changes in $\mathrm{pH}$ have direct effects on marine bacterial community composition: a microcosm approach. PLoS ONE 7:e47035. doi: 10.1371/journal. pone. 0047035

Lohmann, G., and Wiltshire, K. H. (2012). Winter atmospheric circulation signature for the timing of the spring bloom of diatoms in the North Sea. Mar. Biol. 159, 2573-2581. doi: 10.1007/s00227-012-1993-7

Lyons, M. M., and Dobbs, F. C. (2012). Differential utilization of carbon substrates by aggregate-associated and water-associated heterotrophic bacterial communities. Hydrobiologia 686, 181-193. doi: 10.1007/s10750-012-1010-7

Mopper, K., Zhou, J., Sri Ramana, K., Passow, U., Dam, H. G., and Drapeau, D. T. (1995). The role of surface-active carbohydrates in the flocculation of adiatom bloom in a mesocosm. Deap Sea Res. II 42, 47-73.

Pakulski, J. D., and Benner, R. (1994). Abundance and distribution of carbohydrates in the ocean. Limnol. Oceanogr. 39, 930-940. doi: 10.4319/lo.1994.39.4.0930

Pantoja, S., and Lee, C. (1999). Molecular weight distribution of proteinaceous material in Long Island Sound sediments. Limnol. Oceanogr. 44, 1323-1330. doi: $10.4319 /$ lo.1999.44.5.1323

Passow, U. (2002). Production of transparent exopolymer particles (TEP) by phytoand bacterioplankton. Mar. Ecol. Prog. Ser. 236, 1-12. doi: 10.3354/meps236001

Passow, U., Alldredge, A. L., and Logan, B. E. (1994). The role of particulate carbohydrate exudates in the flocculationof diatom blooms. Deep Sea Res. 41, 335-357. doi: 10.1016/0967-0637(94)90007-8

Pernthaler, A., Pernthaler, J., Schattenhofer, M., and Amann, R. (2002). Identification of DNA-synthesising bacterial cells in coastal North Sea Plankton. Appl. Environ. Microbiol. 68, 5728-5736. doi: 10.1128/AEM.68.11.5728-5736. 2002

Pinhassi, J., Sala, M. M., Havskum, H., Peters, F., Guadayol, O., Malits, A., et al. (2004). Changes in bacterioplankton composition under different phytoplankton regimens. Appl. Environ. Microbiol. 70, 6753-6766. doi: 10.1128/ AEM.70.11.6753-6766.2004

Piontek, J., Borchard, C., Sperling, M., Schulz, K. G., Riebesell, U., and Engel, A. (2013). Response of bacterioplankton activity in an Arctic fjord system to elevated pCO2: results from a mesocosm study. Biogesciences 10, 297-314. doi: 10.5194/bg-10-297-2013

Piontek, J., Händel, N., de Bodt, C., Harlay, J., Chou, L., and Engel, A. (2011). The utilization of polysaccharides by heterotrophic bacterioplankton in the Bay of Biscay (North Atlantic Ocean). J. Plankton Res. 33, 1719-1735. doi: 10.1093/plankt/fbr069

Ranjard, L., Brothier, E., and Nazaret, S. (2000). Sequencing bands of ribosomal intergenic spacer analysis fingerprints for characterization and microscale distribution of soil bacterium populations responding to mercury spiking. Appl. Environ. Microbiol. 66, 5334-5339. doi: 10.1128/AEM.66.12.53345339.2000
Rich, J., Gosselin, M., Sherr, E., Sherr, B., and Kirchman, D. L. (1997). High bacterial production, uptake and concentrations of dissolved organic matter in the central Arctic Ocean. Deep Sea Res. Part II 44, 1645-1663. doi: 10.1016/ S0967-0645(97)00058-1

Rink, B., Grüner, N., Brinkhoff, T., Ziegelmüller, K., and Simon, M. (2011). Regional patterns of bacterial community composition and biogeochemical properties in the southern North Sea. Aquat. Microb. Ecol. 63, 207-222. doi: 10.3354/ame01493

Rink, B., Seeberger, S., Martens, T., Duerselen, C.-D., Simon, M., and Brinkhoff, T. (2007). Effects of phytoplankton bloom in a coastal ecosystem on the composition of bacterial communities. Auquat. Microb. Ecol. 48, 47-60. doi: 10.3354/ame048047

Rooney-Varga, J. N., Giewat, M. W., Savin, M. C., Sood, S., LeGresley, M., and Martin, J. L. (2005). Links between phytoplankton and bacterial community dynamicsin a coastal marine environment. Microb. Ecol. 49, 163-175. doi: 10. 1007/s00248-003-1057-0

Sapp, M., Wichels, A., Wiltshire, K. H., and Gerdts, G. (2007). Bacterial community dynamics during the winter-spring transition in the North Sea. FEMS Microbiol. Ecol. 59, 622-637. doi: 10.1111/j.1574-6941.2006.00238.x

Sperling, M., Giebel, H.-A., Rink, B., Grayek, S., Staneva, J., Stanev, E., et al. (2012). Differential effect of hydrographic and biogeochemical properties on SAR11 and Roseobacter RCA populations in the southern North Sea. Aquat. Microb. Ecol. 67, 25-34. doi: 10.3354/ame01580

Sperling, M., Piontek, J., Gerdts, G., Wichels, A., Schunck, H., Roy, A.-S., et al. (2013). Effect of elevated $\mathrm{CO} 2$ on the dynamics of particle attached and freeliving bacterioplankton communities in an Arctic fjord. Biogeosciences 10, 181-191. doi: 10.5194/bg-10-181-2013

Steen, A. D., and Arnosti, C. (2011). Long lifetimes of $\beta$-glucosidase, leucine aminopeptidase, and phosphatase in Arctic seawater. Mar. Chem. 123, 127-132. doi: 10.1016/j.marchem.2010.10.006

Storm, S. L., Benner, R., Ziegler, S., and Dagg, M. J. (1997). Planktonic grazers are a potentially important source of marine dissolved organic carbon. Limnol. Oceanogr. 42, 1364-1374. doi: 10.4319/lo.1997.42.6.1364

Sugimura, Y., and Suzuki, Y. (1988). A high-temperature catalytic oxidation method for the determination of non-volatile dissolved organic carbon in seawater by direct injection of a liquid sample. Mar. Chem. 24, 105-131. doi: 10.1016/0304-4203(88)90043-6

Tanaka, T., Thingstad, T. F., Løvdal, T., Grossart, H.-P., Larsen, A., Allgaier, M., et al. (2008). Availability of phosphate for phytoplankton and bacteria and of glucose for bacteria at different $\mathrm{pCO} 2$ levels in a mesocosm study. Biogeosciences 5, 669-678. doi: 10.5194/bg-5-669-2008

Taylor, J. D., Cottingham, S. D., Billinge, J., and Cunliffe, M. (2014). Seasonal microbial community dynamics correlate with phytoplankton-derived polysaccharides in surface coastal waters. ISME J. 8, 245-248. doi: 10.1038/ ismej.2013.178

Teeling, H., Fuchs, B. M., Becher, D., Klockow, C., Gardebrecht, A., Bennke, C. M., et al. (2012). Substrate-controlled succession of marine bacterioplankton populations induced by a phytoplankton bloom. Science 336, 608-611. doi: $10.1126 /$ science. 1218344

Teeling, H., Fuchs, B. M., Bennke, C. B., Krüger, K., Chafee, M., Kappelmann, L., et al. (2016). Recurring patterns in bacterioplankton dynamics during coastal spring algae blooms. Elife 5:e1188. doi: 10.7554/eLife.11888

Veldhuis, M. J. W., Admiraal, W., and Colijn, F. (1986). Chemical and physiological changes of phytoplankton during the spring bloom, dominated by Phaeocystis pouchetii (Haptophyceae): observations in dutch coastal waters of the North Sea. Neth. J. Sea Res. 20, 49-60. doi: 10.1016/0077-7579(86)90060-8

Weiss, M. S., Abele, U., Weckesser, J., Welte, W., Schiltz, E., and Schulz, G. E. (1991). Molecular architecture and electrostatic properties of a bacterial porin. Science 254, 1627-1630. doi: 10.1126/science.1721242

Wiltshire, K. H., Kraberg, A., Bartsch, I., Boersma, M., Franke, H.-D., Freund, J., et al. (2009). Helgoland Roads, North Sea: 45 years of change. Estuaries Coasts $33,295-310$.

Wiltshire, K. H., Malzahn, A. M., Wirtz, K., Greve, W., Janisch, S., Mangelsdorf, P., et al. (2008). Resilience of North Sea phytoplankton spring bloom dynamics: an analysis of long-term data at Helgoland Roads. Limnol. Oceanogr. 53, 1294-1302. doi: 10.4319/lo.2008.53.4.1294

Wiltshire, K. H., and Manly, B. F. J. (2004). The warming trend at Helgoland Roads, North Sea: phytoplankton response. Helgol. Mar. Res. 58, 269-273. 
Zimmerman, A. E., Martiny, A. C., Allison, S. D. (2013). Microdiversity of extracellular enzyme genes among sequenced prokaryotic genomes. ISME J. 7, 1187-1199. doi: 10.1038/ismej.2012.176

Conflict of Interest Statement: The authors declare that the research was conducted in the absence of any commercial or financial relationships that could be construed as a potential conflict of interest.
Copyright (c) 2017 Sperling, Piontek, Engel, Wiltshire, Niggemann, Gerdts and Wichels. This is an open-access article distributed under the terms of the Creative Commons Attribution License (CC BY). The use, distribution or reproduction in other forums is permitted, provided the original author(s) or licensor are credited and that the original publication in this journal is cited, in accordance with accepted academic practice. No use, distribution or reproduction is permitted which does not comply with these terms. 